\title{
Impact of Cluster Front Line Demonstrations (CFLDS) on Toria (Brassica campestris L.) in Lakhimpur District of Assam, India
}

\author{
Lakshi Kt Nath*, B. C. Deka and A. Chakraborty
}

Krishi Vigyan Kendra, Lakhimpur, Assam Agricultural University, India

*Corresponding author

Keywords

Toria, Cluster front line demonstration,

Extension gap,

Technology gap,

Technology index

Article Info

Accepted:

15 April 2020

Available Online:

10 May 2020

\section{A B S T R A C T}

Two hundred thirty two Cluster Front Line Demonstrations on toria were conducted at six different blocks of Lakhimpur district of Assam during 2015-16 to 2018-19. The average yield of toria varieties under demonstration was $982 \mathrm{~kg} / \mathrm{ha}$ as compared to $641 \mathrm{~kg} / \mathrm{ha}$ in farmers practice. The highest yield of toria was recorded in Telahi $(1055 \mathrm{~kg} / \mathrm{ha})$ block followed by Lakhimpur block ( $992 \mathrm{~kg} / \mathrm{ha}$ ). Among the blocks, the yield gap was higher in Telahi block followed by Lakhimpur ranging from 301 to $420 \mathrm{~kg} / \mathrm{ha}$. There is urgent need to make stronger extension services for educating the farmers in the implementation of improved technology. The technology gap of 145 to $252 \mathrm{~kg} / \mathrm{ha}$ was recorded with the technology index of 12.08 to 21.0 per cent which indicated the need to educate farmers and lower the technology index showed the feasibility of demonstrated improved technology at location specific farmers' field. The net return (Rs 19,490/ha), additional return (Rs. 12,560/ha), benefit cost ratio (2.37) and incremental benefit cost ratio (14.27) were found higher under improved technology demonstrated at Telahi block as compared to farmers practice.

\section{Introduction}

Oil seeds are rich source of fat and edible oils have various uses for human being and animals. About 90 per cent of the total edible oil produced in the country comes from two oil seed crops namely rapeseed-mustard and groundnut. The oil cakes are also used as cattle feed and manures. In India, rape seed mustard is an important source of edible oil followed by ground nut (Panday et al., 1999). Among the oilseeds grown in India, toria accounts for $22.4 \%$ and $22.6 \%$ of acreage and production respectively during 2011-12. India holds a premier position in toria economy of the world with about $20.2 \%$ acreage and 
$10.7 \%$ production during 2011-12. They occupied an area of about 5.9 million ha with about 6.78 million tonnes production and with an average yield of $1145 \mathrm{~kg} / \mathrm{ha}$ during 2011 12. In Assam, the total cultivated area under toria, total production and average productivity are 2,81,006 ha, 1,87,522 tonnes, and $667 \mathrm{~kg} / \mathrm{ha}$, respectively. In Lakhimpur district the total area under toria is 21,700 ha and the production is 13,888 tonnes with the average productivity of about $640 \mathrm{~kg} / \mathrm{ha}$. Keeping in view the low productivity of toria, the present study was undertaken to study the impact of Cluster Front Line Demonstration (CFLD) on toria in six different blocks of Lakhimpur district of Assam. The Cluster Front Line Demonstration (CFLD) is an applied approach to accelerate the dissemination of proven technologies at farmer's fields in a participatory mode with an objective to explore the maximum available resources of crop production and also to bridge the productivity gaps by enhancing the production in national basket.

\section{Materials and Methods}

Two hundred thirty two numbers of Cluster Front Line Demonstrations (CFLDs) on toria were conducted during 2015-16 to 2018-19 at six different blocks viz., Lakhimpur, Dhakuakhana, Ghilamora, Telahi, Karunabari and Narayanpur of Lakhimpur district of Assam (Table 1). For conducting the demonstrations, farmers were identified/ selected following the survey suggested by Choudhary (1999). The required inputs were supplied and regular visits to the demonstration fields by the KVK scientists ensured proper guidance to the farmers.
Trainings, Field days and group meetings were also organized to provide the opportunities for other farmers to witness the benefits of demonstrated technologies. The sowing was done during mid October to first week of December under rainfed conditions and harvested during mid January to first week of March depending upon the variety. The recommended varieties of TS-38 and TS67 were demonstrated by using the seed rate of $10 \mathrm{~kg} / \mathrm{ha}$. Seed treatment was done with bio-fertilizer (Azotobacter and PSB@ $50 \mathrm{~g} / \mathrm{kg}$ seed), Vermicompost @ 2.5q/ha and Borax @ $10 \mathrm{~kg} / \mathrm{ha}$ were also applied in demonstration along with $50 \%$ recommended dose of $\mathrm{N}, \mathrm{P}$ and full dose of $\mathrm{K}$ fertilizer. However, the practices followed by farmers in general use local variety mainly M-27 with the seed rate ranged from $15-20 \mathrm{~kg} / \mathrm{ha}$, no seed treatment, sowing from last week of October to last week of November, in broadcasting manner. Field days and group meetings were also organized to provide the opportunities for other farmers to witness the benefits of demonstrated technologies. The yield data for demonstrated improved technology (IT) and farmers' practice (FP) were collected from the equal areas. The demonstration was conducted to study the gaps between the potential yield and demonstration yield, extension gap and technology index. In the present evaluation study, the data on output of toria cultivation were collected from demonstrated plots, besides the data on local practices commonly adopted by the farmers of the district were also collected.

To estimate the technology gap, extension gap and technology index, the formulae (Samui et. $a l ., 2000)$ has been depicted as:

$$
\begin{gathered}
\text { Technology gap }=\text { Potential yield }- \text { Demonstration yield } \\
\text { Extension gap }=\text { Demonstration yield }- \text { Farmers yield }
\end{gathered}
$$


Technology index =

Potential yield - Demonstration yield x 100

Potential yield

Additional return $=$ Demonstration return - Farmers practice return

Incremental B: $\mathrm{C}$ ratio $=\frac{\text { Additional return }}{\text { Additional cost }}$

To estimate the impact in terms of monetary benefits, the benefit cost ratio (BCR) analysis of improved technology (IT) over the real farmers' practices (FP) was worked out with the prevailing market value of the crop.

\section{Results and Discussion}

\section{Yield gaps}

The data presented in Table-2 indicated that the average seed yield of toria varieties under demonstration was $982 \mathrm{~kg} / \mathrm{ha}$ as compared to $641 \mathrm{~kg} / \mathrm{ha}$ in farmers practice. This indicated that the use of improved varieties along with improved technology contributed 53.20 per cent higher production than farmers' traditional varieties. The highest yield of toria was recorded in Telahi $(1055 \mathrm{~kg} / \mathrm{ha})$ block followed by Lakhimpur block $(992 \mathrm{~kg} / \mathrm{ha})$. The lowest demonstrated toria yield of 948 $\mathrm{kg} / \mathrm{ha}$ was recorded in Dhakuakhana development block.

The technology gap which corroborates to the gap in demonstration yield over potential yield ranged from $145 \mathrm{~kg} / \mathrm{ha}$ at Telahi block to $252 \mathrm{~kg} / \mathrm{ha}$ at Dhakuakhana block. The technology gap observed may be attributed to dissimilarity in soil fertility status, topography, sowing time and weather conditions at different blocks in the district. Hence, location specific recommendations appear to be necessary to bridge the gap between the yields of toria. The highest extension gap was found at Telahi block followed by Lakhimpur block which emphasized the need to educate the farmers' to adopt improved agro-technologies to reverse the trend of wide extension gap. More and more use of HYVs by the farmers may subsequently change this alarming trend of galloping extension gaps (Sarma et al., 2014). The new technologies will eventually lead to the farmers to disenchantment discontinuance of old varieties with new technology. The technology index showed the feasibility of evolved technologies at farmer's field. The lowest technology index of 12.08 per cent at Telahi block and highest technology index of 21.0 per cent at Dhakuakhana block which indicated that lower the value of technology index, more is the feasibility of the technology demonstrated (Table-2).

\section{Economic analysis}

The gross return (Rs. 33,760/ha), net return (Rs.19,490/ha), additional return (Rs. $12,560 /$ ha), benefit cost ratio (2.37) and incremental benefit cost ratio (14.27) were found higher under improved technology demonstrated at Telahi block followed by Lakhimpur block as compared to farmers practice (Table-3). Hence, higher benefit cost ratio proved economic viability of the improved technology (IT) demonstrated at different blocks in Lakhimpur district of Assam. This finding is in conformity with the finding of Balai at el., 2012 in rapeseed and mustard and Sharma, 2003 in moth bean. 
Table.1 Number of Cluster Frontline Demonstrations (CFLDs) on toria conducted in different blocks of Lakhimpur district of Assam (2015-16 to 2018-19)

\begin{tabular}{|l|c|c|c|c|c|}
\hline \multirow{2}{*}{ Blocks } & \multicolumn{4}{|c|}{ Demonstration conducted } & \multirow{2}{*}{ Total } \\
\cline { 2 - 6 } & $\mathbf{2 0 1 5 - 1 6}$ & $\mathbf{2 0 1 6 - 1 7}$ & $\mathbf{2 0 1 7 - 1 8}$ & $\mathbf{2 0 1 8 - 1 9}$ & \\
\hline Lakhimpur & 4 & 15 & 8 & 3 & 30 \\
\hline Dhakuakhana & & 7 & 88 & & 95 \\
\hline Ghilamora & & 5 & 2 & & 15 \\
\hline Telahi & 1 & & 7 & 64 & 89 \\
\hline Karunabari & & & 5 & & 15 \\
\hline Narayanpur & & & 15 & $\mathbf{7 5}$ & $\mathbf{2 3 2}$ \\
\hline Total & $\mathbf{0 5}$ & $\mathbf{2 7}$ & $\mathbf{1 2 5}$ & & \\
\hline
\end{tabular}

Table.2 Yield gaps analysis of Cluster Frontline Demonstrations (CFLDs) on toria in different blocks of Lakhimpur district of Assam (2015-16 to 2018-19). (4 years pooled)

\begin{tabular}{|c|c|c|c|c|c|c|c|}
\hline \multirow[t]{2}{*}{ Blocks } & \multicolumn{3}{|c|}{ Yield (kg/ha) } & \multirow{2}{*}{$\begin{array}{c}\% \\
\text { increase }\end{array}$} & \multirow{2}{*}{$\begin{array}{l}\text { Technology } \\
\text { gap (kg/ha) }\end{array}$} & \multirow{2}{*}{$\begin{array}{l}\text { Extension } \\
\text { gap (kg/ha) }\end{array}$} & \multirow{2}{*}{$\begin{array}{l}\text { Technology } \\
\text { index }(\%)\end{array}$} \\
\hline & Potential & IT & FP & & & & \\
\hline Lakhimpur & 1200 & 992 & 639 & 55.24 & 208 & 353 & 17.33 \\
\hline Dhakuakhana & 1200 & 948 & 647 & 46.52 & 252 & 301 & 21.00 \\
\hline Ghilamora & 1200 & 968 & 657 & 47.34 & 232 & 311 & 19.33 \\
\hline Telahi & 1200 & 1055 & 635 & 66.14 & 145 & 420 & 12.08 \\
\hline Karunabari & 1200 & 951 & 643 & 47.90 & 249 & 308 & 20.75 \\
\hline Narayanpur & 1200 & 979 & 630 & 55.40 & 221 & 349 & 18.42 \\
\hline Pooled & 1200 & 982 & 641 & 53.20 & 218 & 341 & 18.17 \\
\hline
\end{tabular}

Table.3 Economic impact of improved technology (IT) on toria over farmers practice (FP) in Lakhimpur, Assam (4 years pooled)

\begin{tabular}{|c|c|c|c|c|c|c|c|c|c|c|}
\hline \multirow[t]{2}{*}{ Blocks } & \multicolumn{2}{|c|}{$\begin{array}{c}\text { Cost of } \\
\text { cultivation } \\
\text { (Rs./ha) }\end{array}$} & \multicolumn{2}{|c|}{$\begin{array}{l}\text { Gross return } \\
\text { (Rs./ha) }\end{array}$} & \multicolumn{2}{|c|}{$\begin{array}{l}\text { Net return } \\
\text { (Rs./ha) }\end{array}$} & \multicolumn{2}{|c|}{ BCR } & \multirow[t]{2}{*}{$\begin{array}{l}\text { Additional } \\
\text { Return } \\
\text { (Rs/ha) }\end{array}$} & \multirow[t]{2}{*}{ IBCR } \\
\hline & IT & FP & IT & FP & IT & FP & IT & FP & & \\
\hline Lakhimpur & 14510 & 13580 & 33728 & 21726 & 19218 & 8146 & 2.32 & 1.60 & 11072 & 11.91 \\
\hline Dhakuakhana & 14880 & 13810 & 31284 & 21351 & 16404 & 7541 & 2.10 & 1.55 & 8863 & 8.28 \\
\hline Ghilamora & 13920 & 12820 & 31944 & 21681 & 18024 & 8861 & 2.29 & 1.69 & 9163 & 8.33 \\
\hline Telahi & 14270 & 13390 & 33760 & 20320 & 19490 & 6930 & 2.37 & 1.52 & 12560 & 14.27 \\
\hline Karunabari & 14840 & 13760 & 32334 & 21862 & 17494 & 8102 & 2.18 & 1.59 & 9392 & 8.70 \\
\hline Narayanpur & 14920 & 13830 & 31328 & 20160 & 16408 & 6330 & 2.10 & 1.46 & 10078 & 9.25 \\
\hline Pooled & 14557 & 13531 & 32396 & 21183 & 17839 & 7652 & 2.23 & 1.57 & 10188 & 10.12 \\
\hline
\end{tabular}


In conclusion, the technologies demonstrated under Cluster Line Demonstrations had been exploited to obtain the maximum yield, net profit and additional income of toria cultivation which lead to economic viability of the farming in the district. The yield and profit gaps between technology demonstrated and farmers practice might be due to biophysical, socio-economic, management, institutional, and policy factors. The highest extension gap reflects the need to educate the farmers through various means for adoption of improved technologies to reverse the trend of wide extension gap.

\section{Acknowledgement}

The authors are grateful to the DEE, Assam Agricultural University, Jorhat and Director, ATARI Guwahati for their support in conducting the programme.

\section{References}

Balai, C. M., Meena, R. P., Meena, B. L. and Bairwa, R. K. (2012). Impact of front line demonstration on rapeseed and mustard yield improvement. Indian
Research Journal of Extension Education 12(2): 113-116.

Choudhary, B.N. (1999). Krishi Vigyan Kendra- guide for KVK managers. Publication, Division of Agril. Extn., ICAR, pp. 73-78.

Panday. I. D, Basudeo Singh, J.N. Sachan. (1999). Brassica hybrid research in India: Status and Prospects. Proceedings of the tenth international rape seed congress. Canberra, Australia.

Samui, S. K., Maitra, S., Roy, D. K., Mondal, A. K. and Saha, D. (2000). Evaluation on frontline demonstration on Groundnut (Arachis hypogaea L.). Journal of the Indian Society of Coastal Agriculture Research 18(2):18-183.

Sarma, H., Sarma, R., Sarmah, A. K. and Upamanya, G. K. (2014). Yield Gap Analysis of Toria (Brassica campestris) in Barpeta District of Assam. Indian Research Journal of Extension Education 14(2): 127-129.

Sharma, O. P. (2003). Moth bean yield improvement through front line demonstration. Agricultural Extension Review 15(5): 11-13.

\section{How to cite this article:}

Lakshi Kt Nath, B. C. Deka and Chakraborty, A. 2020. Impact of Cluster Front Line Demonstrations (CFLDS) on Toria (Brassica campestris L.) in Lakhimpur District of Assam, India. Int.J.Curr.Microbiol.App.Sci. 9(05): 2134-2138. doi: https://doi.org/10.20546/ijcmas.2020.905.243 